\title{
Cultivating the Early Canons: The Pordenone Silent Film Festival
}

\author{
Vito Adriaensens
}

For passionate lovers of silent cinema, the first weekend of October is permanently highlighted in the calendar: it is then that a small city in the north of Italy serves up more than just excellent antipasti and chilled Aperol Spritz. Le Giornate del Cinema Muto, or "the days of silent cinema," commonly known as the Pordenone Silent Film Festival, has been the mecca for film historians and amateurs of mute flickers since its founding in 1982 . The festival is the largest silent film festival in the world, offering a nine-day bombardment of rediscoveries, restorations, retrospectives, and special events from dusk until well past dawn, projected at the proper speeds and accompanied by such leading early cinema musicians as Neil Brand, John Sweeney, and Günter Buchwald. Film history comes alive.

It was here, for instance, that Orson Welles's long-lost slapstick Too Much Johnson (a I938 silent after Mack Sennett intended to be part of a Mercury Theatre Production) was found in a warehouse in 2008 and shown restored in 2013. Needless to say, the festival serves as the premier venue for rediscoveries, with scores of early films found or identified each year. How can films from this period still be discovered today? Note that many archives still have plenty of unidentified film cans lying around.

Furthermore, a significant number of rediscovered films are found in remote locations that were formerly at the very end of the international distribution line, because it was considered cheaper to leave them there than to have them shipped back or destroyed. New Zealand was once such a place; thus Ngā Taonga Sound \& Vision (the New Zealand Archive of Film, Television and Sound Ngā Taonga Whitiāhua Me Ngā Taonga Kōrero) has always been one of the key archival contributors to the festival. A New Zealand garden shed housed Alfred Hitchcock and Graham Cutts's presumed-lost The White Shadow (1924) before it was relocated to the archive in 1989 , where it lay unidentified until 2012; John Ford's Upstream (1927) was discovered, hiding in the

Film Quarterly, Vol. 69, Number 3, pp. 91-95, ISSN 0015-1386, electronic ISSN 1533-8630 (c) 2016 by The Regents of the University of California. All rights reserved. Please direct all requests for permission to photocopy or reproduce article content through the University of California Press's Reprints and Permissions web page, http://www. ucpress.edu/journals.php?p=reprints. DOI: 10.1525/FQ.2016.69.3.91 same deposit of films. It is tempting to speculate that it is only a matter of time before the presumed-missing uncut version of Greed (Erich von Stroheim, I924) turns up in a similarly far-flung locale. If so, Pordenone will more than likely be the first leg on any subsequent international tour.

The Pordenone Silent Film Festival has thus been quite instrumental in the field's understanding of early cinema. Apart from new discoveries, it is one of the only places in the world where it is possible to spend more than a week watching rare prints from archives around the world with many leading silent-film scholars in attendance.

This year's edition (its thirty-fourth) focused on lesserknown masterpieces in the city symphony genre-including Douro, Faina Fluvial (193I), a buzzing portrait of life on and around the Douro River at Porto that constituted the directorial debut of the late and immensely prolific Portuguese filmmaker Manoel de Oliveira. Pordenone also continued a series from last year on the comical side of Russian cinema, finally proving the existence of a Soviet sense of humor; showcased the films of groundbreaking African American performer Bert Williams, the first black man to star in a leading role on Broadway; offered the treat of a few early masterpieces by Victor Fleming; provided an initiation in early Argentinian, Bolivian, and Mexican film culture; and introduced the audience to the popularity of Italian stars in Germany by way of exhilaratingly acrobatic movies starring Italian musclemen Luciano Albertini and Carlo Aldini. ${ }^{\mathrm{I}}$

The Giornate's special events succeeded in mobilizing the local Pordenone population to such an extent that the Teatro Verdi was filled to the brim - and with more than just graying cinephiles. One of the most noteworthy experiences was the presentation of the three-part Japanese jidaigeki, or historical film, Chuji tabinikki (A Diary of Chuji's Travels, Daisuke Ito, 1927) from Japan's oldest studio, Nikkatsu, now known primarily for their hardboiled I950s and ig6os crime films. With almost a hundred credits in the genre to his name, director Daisuke Ito was the godfather of jidaigeki, which were usually set in the Edo period (1603-r868) and typically featured warriors sporting the traditional chonmage 

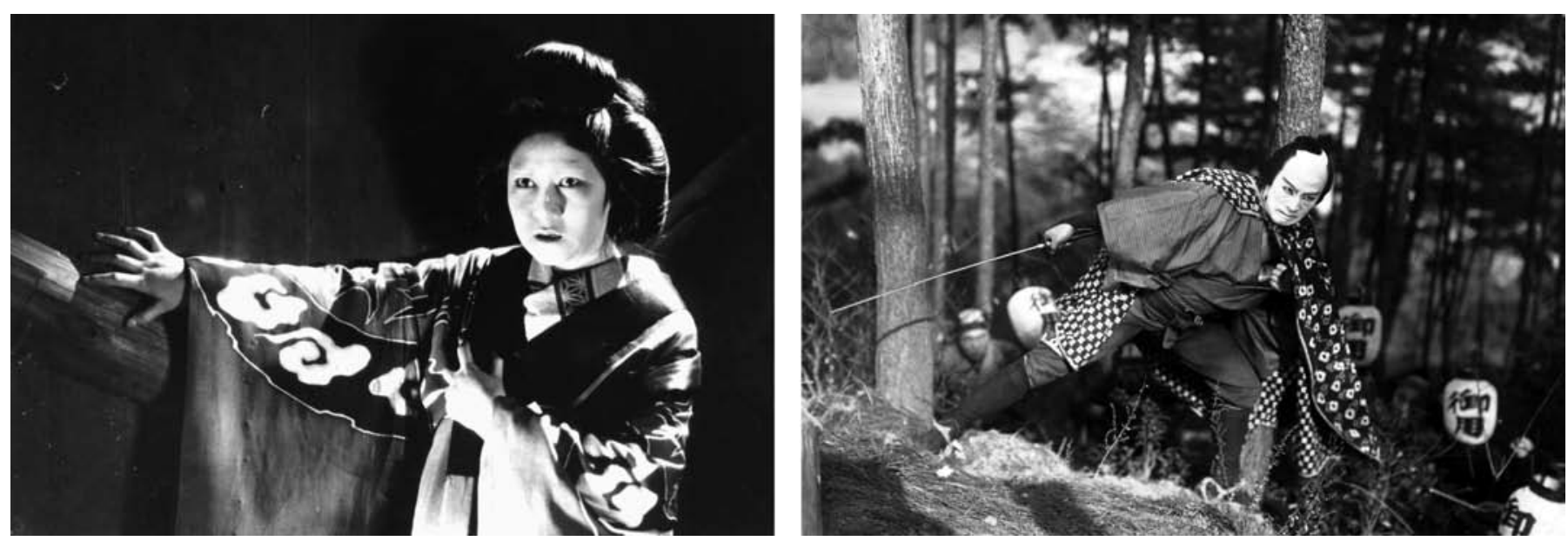

Chuji tabinikki (A Diary of Chuji's Travels, Daisuke Ito, 1927) showcased another side of Japan's Nikkatsu studio.

Photos courtesy of National Film Center, Tokyo

haircut - partly shaved and topped with the ultimate manbun, nearly a century before its hipster revival.

Ito earned the punning nickname Ido daisuki, or "great fan of camera movement," because of his fast-paced visual style; consequently, watching Chuji is like witnessing an early prototype of Akira Kurosawa. The two directors were born only a decade apart; much of their perceived similarity is due to Japanese cinema's predilection for retelling Edo stories about troubled outcast drifters, usually feudal rōnin (samurai without masters), a role that has become iconically associated with Kurosawa regular Toshiro Mifune.

The Pordenone series was based on the actual Chuji Kunisada, a Robin Hood figure with a gambling addiction and a sword quicker than his own shadow, a skill that has provided an excellent opportunity for sword-fighting scenes in which the gloomy protagonist takes on multiple attackers. Chuji has an uncharacteristically nihilistic tone that is more widely associated with the Japanese New Wave, exemplified by the antihero's downfall in the final confrontation of the series, where he becomes crippled and is reduced to watching from the sidelines instead of dying a glorious death in battle.

The Chuji presentation was made into a truly special event through its live accompaniment by benshi Ichiro Kataoka and his three-piece musical ensemble, with a score written especially for this occasion. A benshi traditionally provided silent films with live narration-voicing all of the characters and thereby adding emphases and effects not possible through the intertitles. Being a good benshi requires a proper sense of timing, an ability to do a range of voices, and a sensitivity to the tone of a scene. The benshi also historically helped facilitate the understanding of the plot for the audience, something that became especially apparent in Chujis screening, since the series is not entirely intact. Kataoka was extremely good at providing comic relief via his female voices - a tried-and-true recipe for comedy — and voiced the series' antihero with the slightly over-the-top and gravelly gravitas one has come to expect in Japanese jidaigeki.

Another Giornate presentation, though not billed as a special event, was nevertheless on everyone's minds from the first day: the restoration of Henri Fescourt's 1925-26 rendition of Les Misérables, Victor Hugo's i 862 literary masterpiece. The digital restoration was so beautifully executed that the audience could revel in the wonderful use of color and the clean and crisp nature of the drama at hand. It is true, furthermore, that Henri Fescourt is an undervalued director who deserves more praise, especially in successfully tackling a novel that has always seemed to resist adaptation to the silver screen. The screening was programmed as an event: the four-part serial, which runs almost seven hours, was scheduled as a marathon session with only one break. Although the decision to show it that way no doubt increased the "street cred" of cinephiles who made it through the entire sitting, it is not exactly in keeping with the historical accuracy of its serialization, which is arguably more conducive to viewing pleasure in its original staggered form.

Alas, I must go against the grain by confessing that I did not care much for either the series or the decision to program it as an organic whole. Condensing a literary feat of over a thousand pages into a film is always a problematic venture. Further, because Hugo's work is inherently melodramatic and loses much of its political and cultural nuance on the screen, directors of the adaptations most often focus on Jean Valjean (Gabriel Gabrio) and Fantine's (Sandra Milowanoff) social struggle. In Fescourt's Les Misérables this has resulted in a classic overplaying of the key parts for emotion. Although Gabrio and Milowanoff are clearly deserving actors, the situation in 


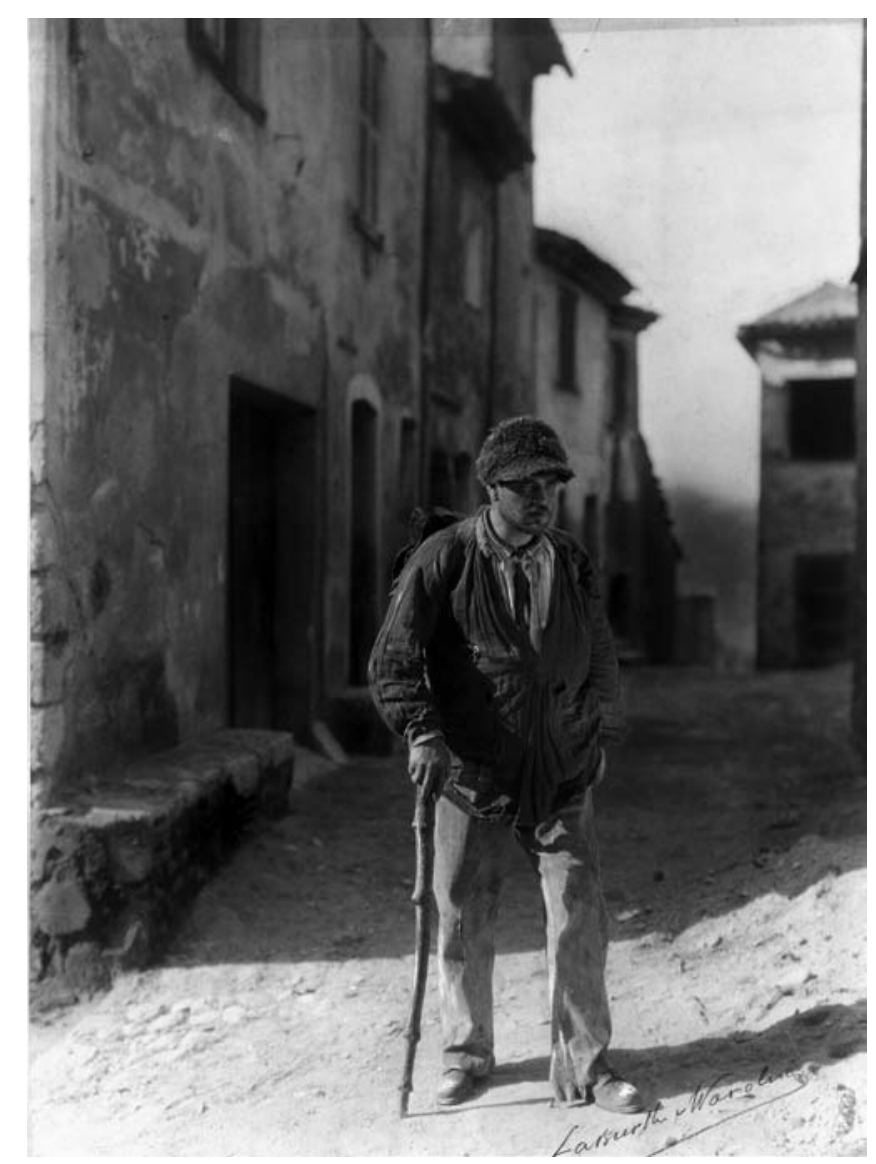

A beautiful digital restoration of Henri Fescourt's curiosity Les Misérables. Photo courtesy of Fondation Jérôme Seydoux-Pathé

which their characters find themselves can provide the viewer with enough dramatic incentive without further need for declamatory emphasis of the kind displayed here. By I925, actors and directors had already been demonstrating a knack for more naturalist performances for more than a decade, yet the combined running time and acting style turned the series into a stilted and somewhat burdensome ordeal.Furthermore, Fescourt's Les Misérables is neither cinematographically innovative nor awe-inspiring for its time. Beautifully restored, yes, but more curiosity than masterpiece.

Fortunately, at the other end of the spectrum of special events stood a lowbrow eighteen-minute two-reeler from I 927 that packed the house and provided instant gratification for all, present company included. Relentless in its efficacy was the rediscovery of one of the great scenes of film history: a long-lost epic custard pie fight. The pie fight is considered to be a slapstick cliché, but it actually occurred far less frequently than one imagines. The legendary missing reel is a three-thousand-pie extravaganza featuring Laurel and Hardy and known as The Battle of the Century (with none other than Clyde Bruckman directing, Leo McCarey supervising, George Stevens shooting, and Hal Roach

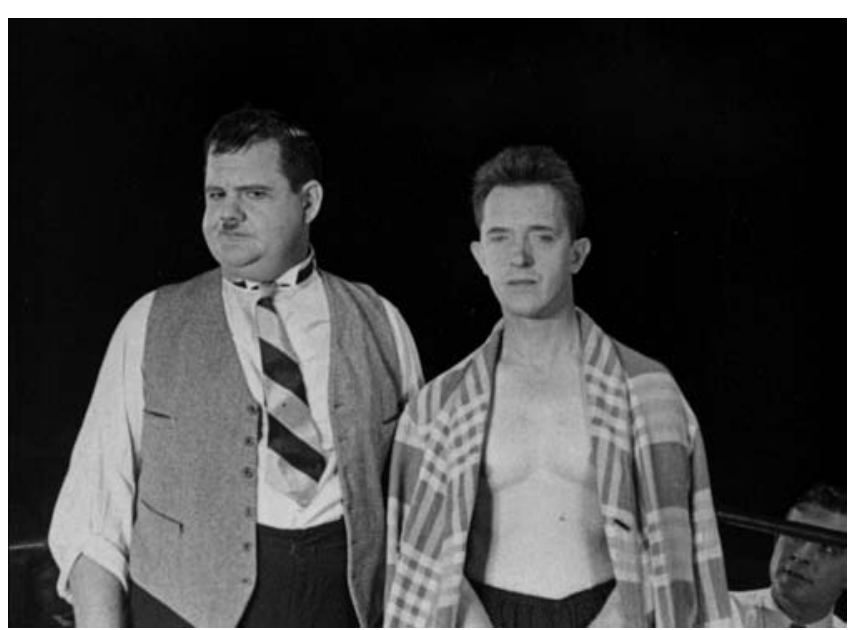

Oliver Hardy and Stan Laurel before the pies start flying in Battle of the Century. Photo courtesy of Lobster Films, Paris

producing). Considered one of the holy grails of comedy, the missing reel was miraculously uncovered in a private collection in 2015. [Editor's note: See J.M. Tyree's tale of its discovery at the Mostly Lost 4 workshop in FQ 69:2.] The film canister had been clearly labeled "The Battle of the Century R2," but over time had somehow escaped the interest or knowledge of prior owners, more than likely lost in the magnitude of the collection.

The two-reeler is only the second official collaboration between Stan Laurel and Oliver Hardy but it is instantly recognizable. What's more, the film exceeds all expectations twice over by its inclusion of another instance of comedy gold, the banana peel. The plot of the film has Stan pegged as a wimpy boxer with Ollie for a manager. With Stan a failure as a fighter, Ollie decides that the only way to make money off his friend is to purchase proper accident insurance for him and then instigate an accident. The burly manager's weapon of choice is a banana peel, but Stan manages to evade it by chance, causing others to slip and take their rage out on the comic duo. As with all great bits, the repetition of the joke does not make it any less funny. When a pie-delivery man finally falls victim to the banana peel, he sticks with what he knows and launches some fresh custard. Once again, the intended targets are not hit, they all try to exact revenge using another pie from the delivery van, and soon the situation escalates into several Mexican standoffs of the dessert variety, with the joke repeated until the streets are paved with pies.

A visit to the Giornate makes clear its important role as a film historical gatekeeper, a position that the festival has only recently fully claimed by launching its "Canon Revisited" series. Since the festival program averages some twenty films a day and has screened around a remarkable seven thousand 


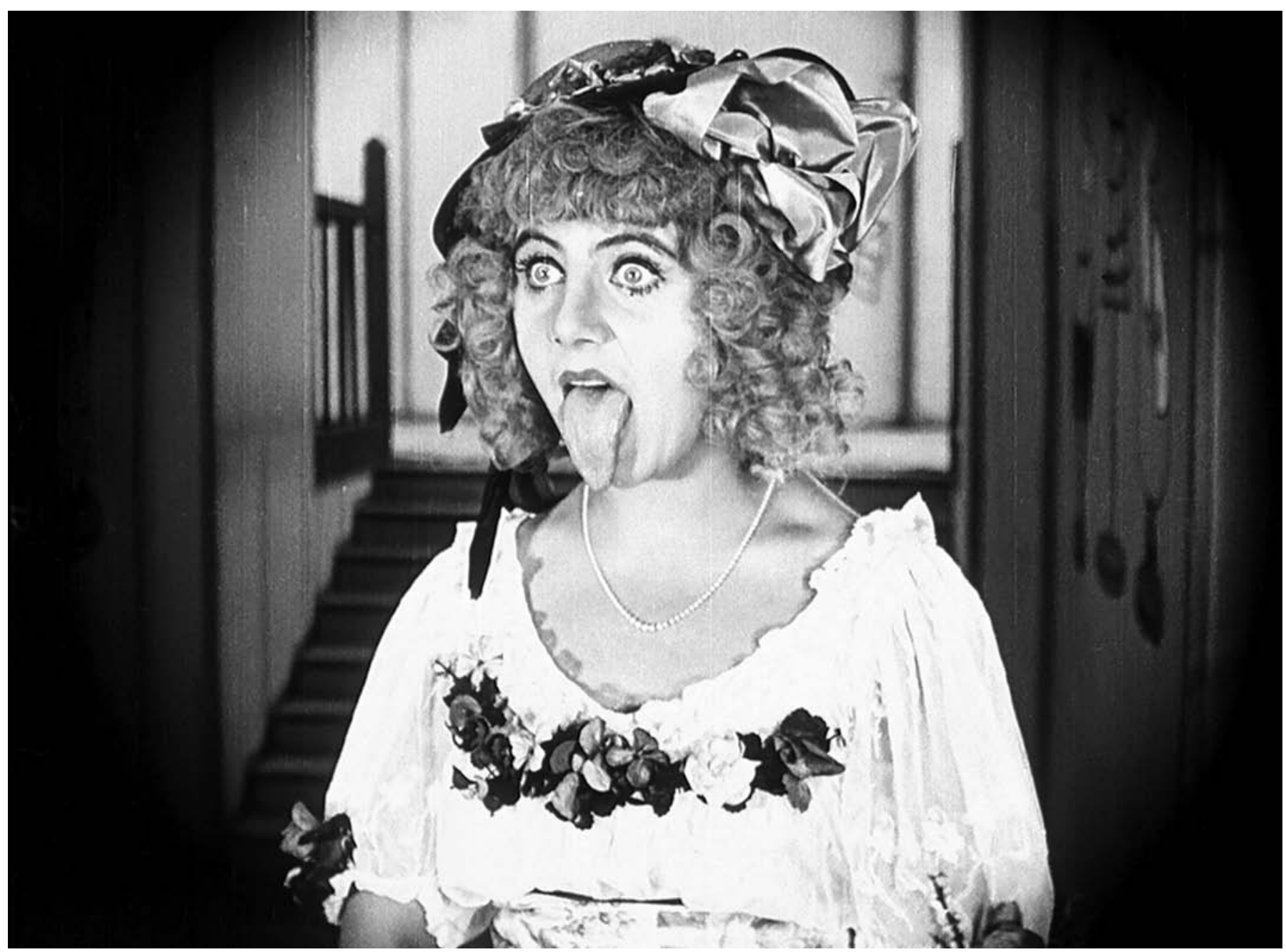

Ernst Lubitsch's Die Puppe (1919) is a sex comedy disguised as a fairy tale. Photo courtesy of Friedrich-Wilhelm-Murnau-Stiftung, Wiesbaden

films to date, its directors felt the need to attempt a canonization of sorts with a program mainstay that, beginning in 2009, would single out six to seven films yearly. Paolo Cherchi Usai, the film historian, senior curator of the George Eastman Museum, and co-founder of the Giornate, explained the festival's canonization efforts at the time of its launch. ${ }^{2}$

Now that we know so much more about the production surrounding the acclaimed milestones of silent cinema, a number of questions are rising to the surface. Why were these milestones treated as such, and how did they become what they are? Who first established their authoritative position in film history? What were the criteria underlying their establishment of the first silent pantheon of cinema? Did they make the right choices? If we think they didn't, how do we validate our presumption that we know better? In which cultural environment were our predecessors adopting the term "masterpiece" for the films they so strongly believed in? There are plenty of reasons for us to revisit the Canon of silent cinema.
This year the Giornate singled out six films, most well known to cinephiles with an eye on early cinema, but certainly not to the wider public. Benjamin Christensen's spy masterpiece in silhouettes, Det Hemmelighedsfulde $X$ (The Mysterious X, I9I4), from Denmark's first cinematic golden age, was chosen because of the efficacy and splendor of its pictorial devices, with certain compositions verging on the abstract, yet capable of striking an emotional chord with audiences. Marcel L'Herbier's hypnotically surreal and frantically impressionist collaboration with artist Fernand Léger, L'Inhumaine (1924), is a pinnacle of the I920s avant-garde long overlooked in favor of the work of Abel Gance. The delightful The Mark of Zorro (Fred Niblo, 1920), a perfect vehicle for Douglas Fairbanks's signature blend of acrobatics and rom-com charm, epitomizes the success of American cinema and one of its greatest international stars. Sergei Eisenstein's ambitious Oktyabr (October, I928), the follow-up to his perennial canon-topper Bronenosets Potemkin (Battleship Potemkin, I925), was chosen precisely because it dared 
to be radically different from its predecessor, yet it is often removed from consideration of canonization because of its strong formalism. Ernst Lubitsch's Die Puppe (1919) is a sex comedy disguised as a fairy tale in which a man, forced to look for a wife, instead finds a doll; it is a strange film by any measure that foreshadows the cinematic symbolism, surrealism, and expressionism of the I920s with abstract minimalist décor and dolls coming to life. It is highly reminiscent of similar scenographical developments in the theater, which came to be known as the "New Stagecraft," especially the artistry of Adolphe Appia, Edward Gordon Craig, and Max Reinhardt. The Rat (I925), a British film by Graham Cutts featuring Ivor Novello as a Parisian "apache," is perhaps the only odd one out as it is truly a forgotten film that was considered a first-class picture in its own era.

Only time will tell if the Giornate's overt canonization efforts will succeed in shaping collective memory. Most certainly this will be a gradual process, since Giornate selection does not wield the same power (yet) as an online poll or media judgment. The Giornate's silent canons have, however, made their way into the film history books, since the festival remains the place for film historians to discover early cinema in its many guises. The Canon Rediscovered series is an admirable program mainstay, but the festival has a lot more on offer each year, aside from its magnificent location in culinarily delightful Pordenone. Where else could one see a thousand people fill a theatre to see a rediscovered Laurel and Hardy two-reeler or a seven-hour rendition of Les Misérables? This year's program can boast introducing moviegoers to a proto-Kurosawa and the art of benshi, or uncovering the joy inherent in watching muscly Italian men bound effortlessly from building to building. It challenged viewers' perception of cities and exotic locales through documentaries that were exhilaratingly experimental, or added a welcome comic layer to a Soviet cinema not exactly known for its chuckles. In short, while not every picture may be a showstopper, the Giornate still has many treasures to yield for cinephiles new and old, from chests that are thankfully replenished every year.

\section{Notes}

I. See the website for a selection of revealing period pictures: http://ivoblom.wordpress.com/20 I5/o9/30/italian-muscleabroad-in-pordenone/.

2. Paolo Cherchi Usai, "Il canone rivisitato/The Canon Revisited I," in Catalogo 2009: Le Giornate del Cinema Muto, ed. Catherine A. Surowiec (Pordenone: La Cineteca del Friuli \& Cinemazero, 2009), 92. 